\title{
Preface to the Cornell Paperbacks Edition
}

Although the epilogue to Catholics and Contraception takes the narrative beyond the 1960s, it does not address recent developments in American Catholicism. I am grateful, then, to have the opportunity to bring the story up to date. Recent developments have unfolded in ways consistent with the argument I make in the epilogue. That argument centers on the pastoral disaster that flowed, without anyone's having intended it, from the fait accompli that abruptly ended the intra-Catholic debate over birth control.

Two events seem particularly worthy of mention. The first is the fortieth anniversary of Humanae Vitae (Of Human Life), the papal encyclical that affirmed the Catholic ban on all modes of artificial contraception. So few American Catholics seem to be aware of this anniversary that it almost qualifies as a "non-event"-in itself a phenomenon worthy of note. The second event, if such it can be called, is the clerical sex abuse scandal that has recently rocked the American Catholic Church. The roots of this scandal are admittedly tangled, having as much to do with the complexities of human sexuality as the evasion of responsibility by church leaders. But it is no accident that the problem was most severe among men ordained in the immediate aftermath of the crisis over contraception. As the epilogue to this book explains, Humanae Vitae gave rise to a church of silence with regard to sex-something that had seriously negative consequences for priestly morale. Silence bred sexual confusion, too, given the turbulence of the times, and this confusion was not confined to the laity.

The reign of silence also explains why so few Catholics today seem to know much about Humanae Vitae or the teaching it endorsed. Catholics have long been virtually indistinguishable from other Americans when it comes to contraceptive use, assuming that one adjusts for income and education. A glance around the Catholic pews on any Sunday morning will reveal a preponderance of two-child families. If Catholics are aware of distinctiveness in their church's sexual teaching, it is generally on the subject of abortion, about which church leaders have been vocal. Indeed, for many younger Catholics, if I can refer- 
ence my long experience with Catholic college students, the immorality of abortion-which they mostly accept, even when they do not embrace their church's absolute prohibition-makes responsible use of contraception a moral imperative. Most would find it impossible to reconstruct the arguments on which Humanae Vitae rests.

Given the mentality of Catholics today, I sometimes wondered in the course of my research whether Catholics and Contraception would have much relevance for anybody under sixty. But in the end, I found I was writing mainly for those many Catholics who regard Humanae Vitae as dim and ancient history. Without taking birth control into account, such persons cannot understand the Catholic world of their parents and grandparents-which is to say, themselves. They also need to understand that the problem of contraception is, for Catholics, buried but not yet dead. It affects their lives in significant ways. Indeed, Catholics will likely hear more references from their bishops to the ban on contraception as political tussling over gay marriage intensifies. If sex is meant primarily for purposes of procreation, one has impeccable grounds on which to oppose homosexual unions. Heterosexual Catholics may naturally feel, as this happens, that the integrity of their moral lives is being held hostage to politics. But if they do, their experience will not be so different from that of lay Catholics in the 1960s. History, it seems, has its uses.

An additional word is in order about the clerical sex abuse scandals, given the extent to which I have relied in my later chapters on interviews with older priests. One of my informants, although not a man I quote, has in fact been removed from the priesthood for what can only be called sexual crimes. Did this unhappy news cause me to revise the high opinion I had of my informants generally? I can say honestly that it did not. In fact, the sex abuse scandalsdevastating though they were to me, as to other Catholics-made me more appreciative than I previously had been of the demoralized circumstances in which priesthood has been lived over the past half-century. Priests of integrity, I have come to realize, deserve even more admiration than I originally accorded them. Theirs has not been an easy road. 